\title{
Intramammary lipopolysaccharide infusion alters gene expression but does not induce lysis of the bovine corpus luteum
}

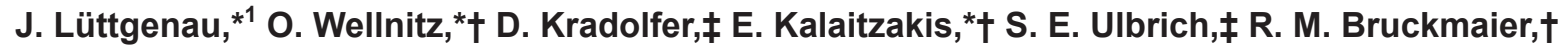 \\ and $\mathrm{H}$. Bollwein* \\ ${ }^{*}$ Clinic of Reproductive Medicine, Vetsuisse Faculty, University of Zurich, CH-8057 Zurich, Switzerland \\ †Veterinary Physiology, Vetsuisse Faculty, University of Bern, CH-3001 Bern, Switzerland \\ fETH Zurich, Animal Physiology, Institute of Agricultural Sciences, $\mathrm{CH}-8092$ Zurich, Switzerland
}

\begin{abstract}
Data from various studies indicate that the ovarian function in dairy cows can be compromised during intramammary infections. Therefore, in this study, we investigated if an experimentally induced mastitis has an effect on corpus luteum (CL) function in 14 lactating cows. On d 9 of the estrous cycle (d $1=$ ovulation), cows received a single dose of $200 \mu \mathrm{g}$ of Escherichia coli lipopolysaccharide (LPS; dissolved in $10 \mathrm{~mL}$ of NaCL; $\mathrm{n}=8$ ) or $10 \mathrm{~mL}$ of saline (control; $\mathrm{n}=6$ ) into one quarter of the mammary gland. Measurements included plasma cortisol, haptoglobin, and progesterone $\left(\mathrm{P}_{4}\right)$ concentrations, as well as luteal size (LTA) and relative luteal blood flow (rLBF). Sampling was performed on $\mathrm{d} 1,4$, and 8 . On $\mathrm{d} 9$, the main examination day, sampling was performed immediately before $(0 \mathrm{~h})$, every 1 $\mathrm{h}$ (or at 3-h intervals for LTA and rLBF) until $9 \mathrm{~h}$, as well as 12 and $24 \mathrm{~h}$ after treatment. Thereafter, measurements were taken on $\mathrm{d} 12,15,18$, and then every $2 \mathrm{~d}$ until ovulation. Luteal tissue was collected for biopsy $24 \mathrm{~h}$ before and $6 \mathrm{~h}$ after treatment. Quantitative real-time PCR was applied to assess mRNA expression of steroidogenic factors (STAR, HSD 3B), caspase 3, toll-like receptors $(T L R 2,-4)$, tumor necrosis factor $\alpha$ $(T N F A)$, and prostaglandin-related factors (PGES, PGFS, PTGFR). Intramammary LPS infusion caused considerable inflammatory responses in the treated udder quarters. No decrease in plasma $\mathrm{P}_{4}$ concentrations was noted after LPS-challenge, and $\mathrm{P}_{4}$ levels did not differ between LPS-treated and control cows. Furthermore, LTA and rLBF values were not decreased after LPS challenge compared with the values obtained immediately before treatment. However, LPS infusion increased plasma levels of cortisol and haptoglobin compared with the control group. In the CL, mRNA
\end{abstract}

Received November 15, 2015

Accepted January 6, 2016.

${ }^{1}$ Corresponding author: jluettgenau@vetclinics.uzh.ch abundance of TLR2 and TNFA was increased in cows after LPS-challenge (but not in control cows), whereas $T L R 4$, steroidogenic, and prostaglandin-related factors remained similar to the mRNA abundance before treatment. In conclusion, intramammary LPS challenge induces systemic inflammatory reactions which alter the luteal mRNA abundance of TLR2 and TNFA but does not induce lysis of the CL.

Key words: corpus luteum, mastitis, inflammation, endotoxin, cow

\section{INTRODUCTION}

For over half a century pregnancy rates in dairy cattle have been decreasing, mainly due to increased embryonic loss (Walsh et al., 2011). The causes of embryonic death are multifarious and the underlying mechanisms are only partly understood. One hypothesis was that inflammatory processes that occur even outside the reproductive tract interfere with embryonic survival and can reduce the fertility of dairy cows.

Mastitis, an inflammation of the mammary gland that often results from bacterial infection, is regarded as the most prevalent disease in dairy cattle (Lavon et al., 2008). Apart from local inflammation of the mammary tissue, mastitis exerts varied systemic effects (Bannerman et al., 2004). Moreover, deterioration of reproductive performance is observed in cows with clinical as well as subclinical mastitis (Pinedo et al., 2009; Lavon et al., 2011a; Roth et al., 2013).

Gram-negative bacteria are responsible for approximately $40 \%$ of all clinical cases of bovine mastitis (Schukken et al., 2012). Clinical mastitis due to gramnegative bacteria has a more detrimental effect on the probability of conception compared with infections caused by other pathogens (Hertl et al., 2010). Among the gram-negative bacteria, Escherichia coli is the most common cause of bovine clinical mastitis (Wilson et al., 1997). This mastitis can be simulated by the intramammary administration of the E. coli endotoxin LPS, which exhibits a dose-dependent inflammatory 
response in the treated quarters of cows (Bruckmaier et al., 1993; Wellnitz et al., 2011, 2015).

Although the exact mechanisms by which intramammary LPS reduces fertility are not clear, LPS-induced cytokines probably play a crucial role. Their effects can be exerted at the level of hypothalamic-pituitary axis, ovary, reproductive tract, or embryo (Hansen et al., 2004). The cytokine IFN- $\alpha$ is able to inhibit the release of the LH from the pituitary (Barros et al., 1992), which leads to anovulation or delayed ovulation in cows. Consistently, the intravenous or intramammary administration of LPS delays ovulation due to decreased LH surges (Lavon et al., 2008). Other cytokines that are enhanced due to mastitis can exert direct effects on the ovary. For instance, IL-6 inhibits estradiol secretion from granulosa cells of the bovine follicle (Alpizar and Spicer, 1994), and tumor necrosis factor (TNF)- $\alpha$ and IFN- $\gamma$ have a toxic effect on bovine luteal cells in vitro (Petroff et al., 2001). Negative effects of mastitis on corpus luteum (CL) function may also be mediated by increased endometrial synthesis of luteolytic $\mathrm{PGF}_{2 \alpha}$ due to elevated blood levels of TNF- $\alpha$ (Skarzynski et al., 2000).

As maintenance of morphological and functional integrity of the CL in cows with inflammatory diseases is an essential precondition for embryonic survival, a recent study (Herzog et al., 2012) investigated the effects of an intravenous treatment with $E$. coli LPS on luteal structure and function using ultrasonography, hormone and gene expression analyses. Both structure and function of the bovine CL were transiently suppressed after LPS challenge. Only a small number of studies have examined the direct effects of inflammation of the mammary gland on the bovine CL. The current study investigates the possible alterations in luteal size, secretory function, and gene expression following LPS-induced clinical mastitis.

\section{MATERIALS AND METHODS}

\section{Cattle}

Sixteen lactating Red Holstein $(\mathrm{n}=10)$, Holstein Friesian $(\mathrm{n}=3)$, and Swiss Fleckvieh $(\mathrm{n}=3)$ cows were enrolled for the purposes of this study. These cows were (mean $\pm \mathrm{SEM}) 5.1 \pm 0.5 \mathrm{yr}$ old, with a $\mathrm{BW}$ of 657.6 $\pm 18.5 \mathrm{~kg}$, and a BCS of 3.0 (median; scale, $1-5$ ). The cows were in mo 2 to $7(4.2 \pm 0.4)$ of lactation 1 to 7 $(3.3 \pm 0.5)$, and were milked twice daily with a bucket milking unit. All cows were clinically healthy and none of the udders showed clinical signs of mastitis. During the experiments, the cows were housed in a tiestall barn and fed high-quality hay, grass, and concentrates with ad libitum access to water. The experimental proce- dures complied with the Swiss Federal Law on Animal Protection and were approved by the Committee of Animal Experiments of the Canton Fribourg, Switzerland.

\section{Study Design}

A modified ovulation synchronization protocol (Ovsynch) was initiated after normal cyclic activity had been confirmed by ultrasonography in all cows. The protocol consisted of $10 \mu \mathrm{g}$ of buserelin $(\mathrm{GnRH}$ analog; Receptal, MSD Animal Health GmbH, Luzern, Switzerland), $15 \mathrm{mg}$ of luprostiol ( $\mathrm{PGF}_{2 \alpha}$ analog; Prosolvin, Virbac AG, Glattbrugg, Switzerland) 7 d later, and finally $10 \mu \mathrm{g}$ of buserelin $60 \mathrm{~h}$ after $\mathrm{PGF}_{2 \alpha}$ (all treatments given i.m.). The time of the second $\mathrm{GnRH}$ application was defined as estrus (d 0). Ovulation, which occurred in all cows within $36 \mathrm{~h}$ after the second $\mathrm{GnRH}$ treatment, was defined as d $1 \mathrm{~h} 0$.

On d 0,1,4, and 8, clinical examination (data not shown), blood sampling, and ultrasonography were performed to verify health and luteal development in cows. Clinical examination included measurements of rectal temperature, respiratory and cardiac frequencies, palpation of the udder, as well as visual examination of conjunctiva and episcleral vessels. An intravenous catheter was inserted into one jugular vein on d 8 (removed after $48 \mathrm{~h}$ ) to facilitate blood sampling during the main examination day (d 9).

After the morning milking on d 9, cows were randomly allocated to receive either a single intramammary treatment with $200 \mu \mathrm{g}$ of E. coli LPS (serotype O26:B6; Sigma Aldrich, Buchs, Switzerland), diluted in $10 \mathrm{~mL}$ of saline solution, or with $10 \mathrm{~mL}$ saline only (control). Within LPS-treated cows, another quarter was infused with $10 \mathrm{~mL}$ of saline (control quarter). Immediately before treatments, the teat tips were carefully disinfected with $70 \%$ ethanol. The treated quarters of the mammary gland were randomly chosen (front or rear, left or right) and equally distributed. Clinical examination and blood sampling was performed immediately before (0 h), hourly until $9 \mathrm{~h}$ (11 h for clinical examination), and 12 and $24 \mathrm{~h}$ after the administration of LPS or saline. Ultrasonographic measurements were performed $0,3,6,9,12$, and $24 \mathrm{~h}$ after treatment, and luteal tissue was collected for biopsy $24 \mathrm{~h}$ before and $6 \mathrm{~h}$ after treatment. Within LPS-treated cows, foremilk samples (approximately $10 \mathrm{~mL}$ ) were collected by hand from LPS-challenged and control quarters hourly between 0 and $2 \mathrm{~h}$, and every $15 \mathrm{~min}$ between 2 and $5 \mathrm{~h}$ after treatment. Milk SCC was measured using a cell counter (DCC; DeLaval, Tumba, Sweden) immediately after collection. Starting on d 12, clinical examination, blood sampling, and ultrasonography were performed every 3 
$\mathrm{d}$, and from d 18 onwards, every $2 \mathrm{~d}$ until ovulation had occurred (or until d 30 if no ovulation was observed).

\section{Collection of Blood and CL Biopsy Samples}

Blood samples were collected from the jugular vein (d 8 to 10) or from the coccygeal blood vessels (all other times) into evacuated tubes containing EDTA as anticoagulant (Vacuette $9 \mathrm{~mL}$ K3EDTA; Greiner BioOne, Kremsmünster, Austria). Tubes were immediately stored on ice and plasma was separated by centrifugation $\left(3,000 \times g\right.$ for $15 \mathrm{~min}$ at $\left.4^{\circ} \mathrm{C}\right)$, and frozen at $-20^{\circ} \mathrm{C}$ until the analyses.

Prior to the collection of CL biopsy samples, caudal epidural anesthesia was provided to the cows by incorporating $50 \mathrm{mg}$ of lidocaine hydrochloride (Lidocain 2\% Streuli; Streuli Pharma AG, Uznach, Switzerland) to reduce rectal contractions. Two samples (approximately $15 \times 1 \times 1 \mathrm{~mm}$ each) were obtained from the maximum diameter of the CL (including cells from the periphery and the center), using a semiautomatic, high-speed biopsy needle (TEMNO Evolution; Fa. Walter, Baruth/Mark, Germany) that was rendered free of RNase (RNase-ExitusPlus; AppliChem, Darmstadt, Germany). For visual control, a portable ultrasound device (GE Logiq e Premium BT11; General Electric Medical System, Solingen, Germany), equipped with a $7.5-\mathrm{MHz}$ convex transducer was used. The biopsy needle and the ultrasound transducer were guided transvaginally using a bearing system (type Hannover) and the CL was placed in front of the vaginal fornix by transrectal manual assistance. Tissue samples were immediately placed in sterile DNase- and RNase-free cryo tubes (Fa. Brand, Wertheim, Germany), frozen in liquid nitrogen, and stored at $-80^{\circ} \mathrm{C}$ until expression analysis. This method allowed repeated biopsy sampling from a single CL without impairing its subsequent function (Tsai et al., 2001; Lüttgenau et al., 2011b; Atli et al., 2012).

\section{Ultrasonography}

Transrectal ultrasonographic examinations of the ovaries were performed using a portable ultrasound device (GE Logiq e Premium BT11), equipped with a 4.0- to $12.0-\mathrm{MHz}$, linear-array transducer. An exhaustive description of this approach was given recently (Lüttgenau et al., 2011a,b). In brief, 3 cross-sectional images with maximal areas were frozen and recorded for every detectable CL (using B-mode ultrasonography). The total area of the CL was measured using computer-assisted image analysis software (PixelFlux Version 1.0; Chameleon Software, Leipzig, Germany).
When a cavity was present within a CL, the cavity area was assessed separately and subtracted from the total area of the CL. The difference between total area of the CL and its cavity was defined as area of luteal tissue (LTA). For each CL, mean values of the measurements of the 3 recorded images were used for data analysis.

The second part of the ultrasonographic examination used Power Mode ultrasonography to assess luteal blood flow (LBF). The transducer was positioned at the maximal diameter of the CL, and small adjustments in location (relative to the ovary) were made to achieve a maximal number of color pixels in the luteal parenchyma before freezing and recording the image. The number of pixels with color was determined (PixelFlux software) as a semiquantitative assessment of LBF. For each CL, 3 images were recorded, and the average number of pixels was used for further analysis. To calculate the relative LBF ( $\mathbf{r L B F}$ ), LBF was divided by LTA.

All ultrasonographic examinations (except from those before and during the Ovsynch protocol) were performed by the same investigator, and the intraclass correlation coefficients of LTA and LBF measurements were 1.00 and 0.99 , respectively.

\section{Plasma Concentration Measurements}

Plasma concentrations of cortisol and haptoglobin were determined with a RIA according to Thun et al. (1981) and with a commercial ELISA (E-10HPT Bovine Haptoglobin ELISA kit; Immunology Consultants Laboratory, Portland, OR), respectively. Intra- and interassay coefficients of variation were 8.5 and $9.1 \%$, respectively, for cortisol, and $<10 \%$ for both assays for haptoglobin.

An RIA (RIA kit IM1188; Beckman Coulter GmbH, Krefeld, Germany) was used to measure plasma progesterone $\left(\mathbf{P}_{4}\right)$ concentrations, and intra- and interassay coefficients of variation were $\leq 6.5$ and $\leq 7.2 \%$, respectively.

Plasma concentrations of prostaglandin $\mathrm{E}_{2}\left(\mathbf{P G E}_{\mathbf{2}}\right)$ and PGF $_{2 \alpha}$ metabolites (PGFM; 13,14-dihydro-15keto- $\mathrm{PGF}_{2 \alpha}$ ) were determined in blood samples collected immediately before treatment, as well as 1 and $2 \mathrm{~h}$ (only for PGFM) and 3, 6, 9, 12, and $24 \mathrm{~h}$ after treatment with a commercial enzyme-immunoassay $\left(\mathrm{PGE}_{2}\right.$ High Sensitivity EIA kit; Enzo Life Sciences AG, Lausen, Switzerland) and with an enzyme-immunoassay according to Mishra et al. (2003), respectively. Commercial PGFM (Sigma Aldrich) was used for the standard curve, and PGFM-horseradish peroxidase conjugate and antiserum were kindly provided by the Department of Physiology in Weihenstephan (Technical University Munich, Germany). Intra- and interas- 
say coefficients of variation were $\leq 9.8$ and $\leq 12.6 \%$ for $\mathrm{PGE}_{2}$, and $\leq 7.5$ and $\leq 12.7 \%$ for PGFM, respectively.

\section{RNA Extraction and Quantitative Real-Time PCR}

Luteal mRNA expression was determined for steroidogenic acute regulatory protein (STAR), $3 \beta$-hydroxysteroid dehydrogenase $(H S D 3 B)$, toll-like receptor (TLR)-2 and -4, TNFA, caspase 3 (CASP3), PGE (PGES/PTGES) and PGF synthases (PGFS) $A K R 1 B 1)$, and PGF receptor $(P T G F R / F P)$. Total RNA from luteal tissue samples was extracted using the miRNeasy Mini Kit (Qiagen, Hilden, Germany). Homogenization of the tissues was achieved with the Qiagen TissueLyser II and 5-mm stainless steel beads (Qiagen). The RNA concentration and integrity were quantified using the NanoDrop 2000 (peqLab, Erlangen, Germany) and the Bioanalyzer 2100 (Agilent Technologies, Waldbronn, Germany), respectively. The RNA integrity numbers ranged from 6.7 to 10 (average 8.3). Five hundred nanograms of RNA were reverse transcribed using the M-MLV Reverse Transcriptase, RNase H Minus, Point Mutant (Promega, Madison, WI), as recently described (Pistek et al., 2013).

Luteal mRNA expression was determined in a 2-step quantitative real-time PCR (qPCR) using the CFX384 Real-Time PCR Detection System (Bio-Rad, Munich, Germany) and the SsoFast EvaGreen Supermix (Bio$\mathrm{Rad})$. The qPCR was performed in a reaction volume of $10 \mu \mathrm{L}$, consisting of $5 \mu \mathrm{L}$ of EvaGreen Mix, $0.4 \mu \mathrm{L}$ of each primer $(10 \mu M), 0.07 \mu \mathrm{L}$ of VisiBlue (TATAA Biocenter, Göteborg, Sweden), $3.13 \mu \mathrm{L}$ of water, and $1 \mu \mathrm{L}$ of cDNA. The primers used to amplify specific fragments referring to selected regulated genes are shown on Table 1 . The annealing temperature and the melting points are outlined. The cycle number $\left(\mathbf{C}_{\mathbf{q}}\right)$ required to achieve a definite SYBR Green fluorescence signal was calculated by the regression method (Bio-Rad CFX Manager 3.1). The $\mathrm{C}_{\mathrm{q}}$ was inversely correlated with the logarithm of the initial template concentration. The $\mathrm{C}_{\mathrm{q}}$ determined for the target genes were normalized against the geometrical mean of the 5 reference genes YWHAZ, H3F3A, CNOT11, SUZ12, and TBP $\left(\Delta \mathrm{C}_{\mathrm{q}}\right)$. The $\Delta \mathrm{C}_{\mathrm{q}}$ was normalized to its mean for all cows on the day before treatment $\left(\Delta \Delta \mathrm{C}_{\mathrm{q}}\right)$. This was done to reduce the intersubject variance due to different baseline expression, which is a major confounding factor in $\mathrm{qPCR}$ experiments (Tichopad et al., 2009). To avoid negative digits, while allowing the estimation of a comparison between 2 genes, data were presented as means \pm standard error of the mean added to the arbitrary value 20 $\left(\Delta \Delta \mathrm{C}_{\mathrm{q}}\right)$. Thus, a high $\Delta \Delta \mathrm{C}_{\mathrm{q}}$ proportionally resembled high transcript abundance (Livak and Schmittgen, 2001).

\section{Statistical Analyses}

Two cows (both from the control group) that ovulated or had mastitis before treatment, were excluded from the study; thus, data from 14 cows were eligible for analyses. One of the 14 included cows (also from the control group) showed mastitis of an untreated quarter on $\mathrm{d} 21$ ( $3 \mathrm{~d}$ before the next ovulation); the measurements of this cow taken between recognition of mastitis and ovulation were omitted from the analysis.

Time between induced (d 1) and subsequent ovulations varied among cows. To facilitate comparability, data were normalized to an average cycle length. Therefore, d 0 to 15 of the cycle were maintained, and $\mathrm{d} 4,2$, and 0 before the subsequent ovulation were used to characterize the remaining cycle. Examination days between d 15 and 4 before the subsequent ovulation were excluded from the analysis. In 3 cows without an ovulation until d 30 (all from the LPS group), the day of ovulation was defined as $2 \mathrm{~d}$ after first occurrence of plasma $\mathrm{P}_{4} \leq 1 \mathrm{ng} / \mathrm{mL}$ (based on the time interval between $\mathrm{P}_{4} \leq 1 \mathrm{ng} / \mathrm{mL}$ and ovulation that was measured for the remaining cows of the study).

Analysis of PGFM had a lower detection limit of $25 \mathrm{pg} / \mathrm{mL}$. For measurements below this limit, $24 \mathrm{pg} /$ $\mathrm{mL}$ was used as an arbitrary value to facilitate statistical analysis. Values of prostaglandin analyses were normalized to their mean on the day before treatment.

Statistical analysis was conducted using SAS V9.3 (SAS Institute Inc., Cary, NC). The distribution of the data was tested for normality visually (PROC CHART) and by means of the Shapiro-Wilk-test (PROC UNIVARIATE). For non-normal data of quantitative variables a Cochran-Mantel-Haenszel test based on rank scores was applied as equivalent to Friedman's 2-way ANOVA for repeated measures (PROC FREQ). Significant results were further evaluated with Wilcoxon's 2-sample test (PROC NPAR1WAY) for independent pairwise comparisons (between groups), and with Wilcoxon's signed rank test (PROC UNIVARIATE) for dependent pairwise comparisons (within group). For normal data of quantitative variables a repeated measures ANOVA (PROC GLM) was performed. Significant results were further evaluated using a 2-sample $t$-test (PROC TTEST) or a Student's $t$-test (PROC UNIVARIATE) for pairwise comparisons between independent and dependent groups, respectively. Differences in categorical variables were evaluated using Fisher's exact test (PROC FREQ). Intraclass correlations for intrarater reliability were calculated by means of the INTRACC macro of SAS (PROC GLM). Data are presented as mean \pm standard error of the mean or median, depending on the distribution of the data, and differences were considered significant at $P \leq 0.05$. 
Table 1. Sequences and accession numbers of PCR primers for assayed genes from bovine corpus luteum cells, and length, annealing (AT) and melting point (MP) temperatures of PCR products

\begin{tabular}{|c|c|c|c|c|c|c|c|}
\hline Gene & $\begin{array}{l}\text { Gene } \\
\text { symbol }\end{array}$ & $\begin{array}{l}\text { Reference } \\
\text { (accession no.) }\end{array}$ & $\begin{array}{l}\text { Forward primer } \\
\left(5^{\prime}-3^{\prime}\right)\end{array}$ & $\begin{array}{l}\text { Reverse primer } \\
\left(5^{\prime}-3^{\prime}\right)\end{array}$ & $\begin{array}{l}\text { PCR } \\
\text { product } \\
\text { (bp) }\end{array}$ & $\begin{array}{l}\mathrm{AT} \\
\left({ }^{\circ} \mathrm{C}\right)\end{array}$ & $\begin{array}{l}\mathrm{MP} \\
\left({ }^{\circ} \mathrm{C}\right)\end{array}$ \\
\hline $\begin{array}{l}\text { Tyrosine } 3 \text {-monooxygenase/ } \\
\text { tryptophan 5-monooxygenase } \\
\text { activation protein, zeta }\end{array}$ & $Y W H A Z$ & NM_174814.2 & AGGCTGAGCGATATGATGAC & GACCCTCCAAGATGACCTAC & 141 & 60 & 81 \\
\hline Histone & НЗFЗА & NM_001014389.2 & ACTGGCTACAAAAGCCGCTC & ACTTGCCTCCTGCAAAGCAC & 233 & 60 & 85 \\
\hline $\begin{array}{l}\text { CCR4-NOT transcription } \\
\text { complex, subunit } 11\end{array}$ & CNOT11 & XM_582695.6 & TCAGTGGACCAAAGCCACCTA & CTCCACACCGGTGCTGTTCT & 170 & 60 & 87 \\
\hline $\begin{array}{l}\text { Suppressor of zeste } 12 \text { homolog } \\
\text { (Drosophila) }\end{array}$ & SUZ12 & NM_001205587.1 & CATCCAAAAGGTGCTAGGATAGATG & TGGGCCTGCACACAAGAATG & 160 & 60 & 82 \\
\hline TATA box binding protein & $T B P$ & NM_001075742.1 & CAGAGAGCTCCGGGATCGT & CACCATCTTCCCAGAACTGAATAT & 194 & 60 & 83 \\
\hline $\begin{array}{l}\text { Steroidogenic acute regulatory } \\
\text { protein }\end{array}$ & $S T A R$ & NM_174189.2 & GGATTAACCAGGTTCGGCG & CTCTCCTTCTTCCAGCCCTC & 157 & 60 & 89 \\
\hline $\begin{array}{l}\text { 3- } \beta \text {-hydroxysteroid } \\
\text { dehydrogenase }\end{array}$ & $H S D 3 B$ & NM_174343.3 & TACCCAGCTGCTGTTGGA & ATGCCGTTGTTATTCAAGGC & 322 & 60 & 87 \\
\hline Caspase 3 & CASP3 & NM_001077840.1 & AACCTCCGTGGATTCAAAATC & TTCAGGRTAATCCATTTTGTAAC ${ }^{1}$ & 114 & 60 & 80 \\
\hline Toll-like receptor 2 & TLR2 & NM_174197.2 & CCATGTGGAGAGGGTGTT & GGGGACACAAAACAGCACTT & 138 & 60 & 81 \\
\hline Toll-like receptor 4 & TLR4 & NM_174198.6 & GACCCTTGCGTACAGGTTGT & GGTCCAGCATCTTGGTTGAT & 103 & 60 & 80 \\
\hline Tumor necrosis factor $\alpha$ & TNFA & NM_173966.3 & CCACGTTGTAGCCGACATC & ACCACCAGCTGGTTGTCTTC & 108 & 60 & 86 \\
\hline Prostaglandin E synthase & $\begin{array}{l}P G E S \\
(P T G E S)\end{array}$ & NM_174443.2 & TCCTGGTCTTCTTCCTGGG & CCCAGACAATCTGCAGGG & 132 & 60 & 88 \\
\hline Prostaglandin F synthase & $\begin{array}{l}P G F S \\
(A K R 1 B 1)\end{array}$ & NM_001012519.1 & ATACAAGCCGGCGGTTAAC & TGTCTGCAATCGCTTTGATC & 188 & 60 & 86 \\
\hline Prostaglandin F receptor & $\begin{array}{l}P T G F R \\
(F P)\end{array}$ & NM_181025.3 & AGCCTTGCCATTGCTATCC & TAGTTCCATTGATGAGGTGCC & 127 & 60 & 80 \\
\hline
\end{tabular}

${ }^{1}$ Degenerate multispecies primer, $\mathrm{R}=\mathrm{A}$ or $\mathrm{G}$. 


\section{RESULTS}

\section{Cows}

Breed, age, BW and BCS, lactation number, month of lactation, and estrous cycle length did not differ between LPS $(\mathrm{n}=8)$ and control groups $(\mathrm{n}=6)$. The proportions of Red Holstein, Holstein Friesian, and Swiss Fleckvieh cows were 50.0, 25.0, and 25.0\%, and 66.7, 16.7, and $16.7 \%$ in LPS and control groups, respectively. The mean ages were $4.6 \pm 0.9$ and $5.1 \pm$ $0.7 \mathrm{yr}$, the BW were $618.8 \pm 27.8$ and $703.5 \pm 20.8 \mathrm{~kg}$, and the median BCS were 2.9 and 3.1 in LPS and control groups, respectively. The cows of the LPS and the control group had mean lactation numbers of $2.8 \pm 0.8$ and $3.2 \pm 0.7$, were in mo $4.8 \pm 0.8$ and $3.7 \pm 0.4$ of lactation, and had an estrous cycle length of $21.8 \pm 0.5$ $(\mathrm{n}=5)$ and $22.0 \pm 0.9 \mathrm{~d}(\mathrm{n}=6)$, respectively. Three cows from the LPS group did not ovulate until d 30 , although $\mathrm{P}_{4}$ concentrations $\leq 1 \mathrm{ng} / \mathrm{mL}$ were observed between $\mathrm{d} 18$ and 26 .

\section{Mastitis}

Two hours after the intramammary infusion with LPS, cows seemed to perceive pain of the treated quarter and kicked with the hind legs toward the udder. The treated quarter was warm, slightly red, and massively swollen.

Somatic cell counts in milk from LPS-challenged quarters increased $(P=0.005)$ from $77 \pm 24 \times 1,000$ cells $/ \mathrm{mL}$ at $0 \mathrm{~h}$ to $390 \pm 116 \times 1,000$ cells $/ \mathrm{mL}$ at $2 \mathrm{~h}$ 45 min after treatment, and increased further until the end of the examination period $(1,149 \pm 191 \times 1,000$ cells $/ \mathrm{mL}$ ). No significant changes of SCC were observed in control quarters. Exhaustive data for SCC and a detailed description of further changes during mastitis in cows of the present study have been reported recently (Wellnitz et al., 2015).

\section{Vital Parameters and Clinical Findings}

Before LPS challenge, rectal temperature and cardiac and respiratory frequencies were in physiological ranges and did not differ between cows of the LPS and the control group (Figure 1). After LPS treatment, rectal temperature increased significantly in all cows at $3 \mathrm{~h}$ and peaked at $6 \mathrm{~h}\left(\right.$ range $\left.=41.1-42.3^{\circ} \mathrm{C}\right)$ before it decreased to initial values (Figure 1A). Cardiac and respiratory frequencies increased significantly to peak values $7 \mathrm{~h}$ after LPS challenge and returned thereafter to initial values (Figure $1 \mathrm{~B}$ and $\mathrm{C}$ ). Rectal temperature and cardiac and respiratory frequencies were higher $(P$ $\leq 0.05$ ) at 2 to 9,4 to 8 , and 6 to $9 \mathrm{~h}$ after treatment in cows of the LPS compared with the control group.
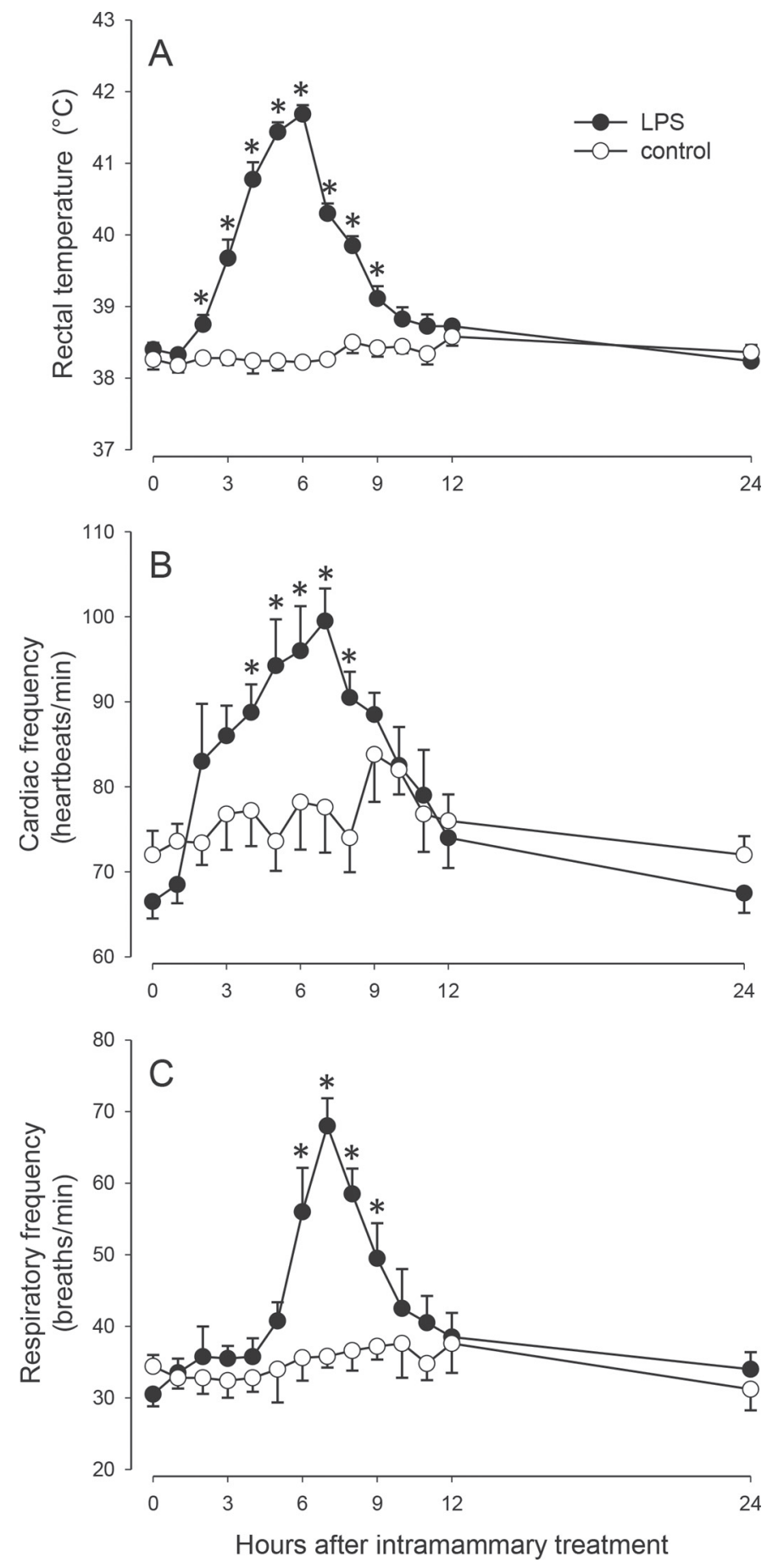

Figure 1. Changes (means $\pm \mathrm{SEM}$ ) in rectal temperature (A), cardiac frequency $(\mathrm{B})$, and respiratory frequency (C) of cows during the first $24 \mathrm{~h}$ after intramammary treatment with either LPS ( $=$ 8 ) or saline (control; $\mathrm{n}=6$ ). An asterisk $(*)$ represents the difference between the 2 groups $(P \leq 0.05)$ at times indicated.

Two hours after intramammary treatment with LPS, cows stopped eating, and during transrectal examinations the rumen appeared to be distended compared 

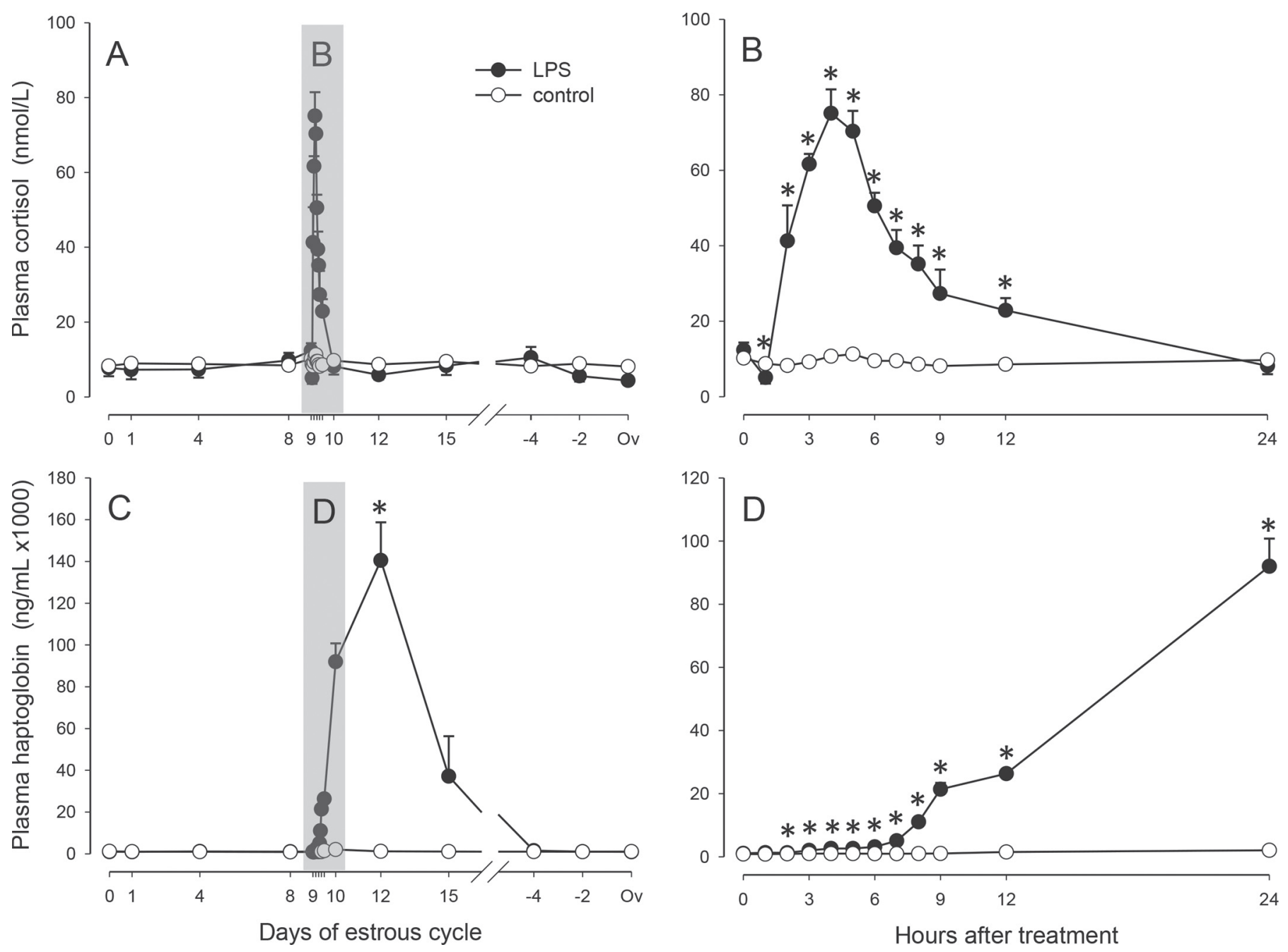

Figure 2. Changes (means \pm SEM) in plasma concentrations of cortisol (A, B) and haptoglobin (C, D) of cows during the whole estrous cycle (A, C) and during the first $24 \mathrm{~h}(\mathrm{~B}, \mathrm{D}$, enlargements of shaded areas in A, C) after intramammary treatment with either LPS (n $=8)$ or saline (control; $\mathrm{n}=6$ ). An asterisk $(*)$ represents the difference between the 2 groups $(P \leq 0.05)$ at times indicated. Day 1 and $\mathrm{Ov}=$ ovulation.

with that of control cows. From 3 to $12 \mathrm{~h}$ after LPS challenge, conjunctiva was reddened in 6 out of 8 cows and episcleral vessels were injected (but not blurred) in 3 out of 8 cows, whereas conjunctiva and episcleral vessels remained unchanged in all cows of the control group.

\section{Plasma Concentrations of Cortisol and Haptoglobin}

Plasma cortisol and haptoglobin concentrations did not differ between cows of the LPS and the control group before treatment (Figure 2A and C). After LPS challenge and in comparison to the values before infusion, cortisol levels increased significantly between 1 and $4 \mathrm{~h}$ and returned to initial values at $24 \mathrm{~h}$ (Figure $2 \mathrm{~A}$ and $\mathrm{B})$. Haptoglobin levels increased significantly from 2 to $72 \mathrm{~h}$ after LPS treatment and returned to initial values thereafter (Figure $2 \mathrm{C}$ and $\mathrm{D}$ ). Cortisol and haptoglobin concentrations were higher $(P \leq 0.02)$ in LPS-treated compared with control cows between 2 and $12 \mathrm{~h}$ and 2 and $72 \mathrm{~h}$ after treatment, respectively.

\section{Plasma Concentrations of Progesterone and Luteal Size and Blood Flow}

Progesterone concentrations did not differ between LPS and control groups during the whole estrous cycle (Figure 3A). However, within the LPS-treated cows a significant increase was noted in plasma $\mathrm{P}_{4}$ levels between 2 and $4 \mathrm{~h}$ after the challenge, and a significant decrease between 4 and $6 \mathrm{~h}$ (Figure 3B).

The LTA in the LPS-treated cows was smaller $24 \mathrm{~h}$ before $(P=0.05)$ and $12 \mathrm{~h}$ after $(P=0.03)$ the challenge compared with the LTA of control cows (Figure 

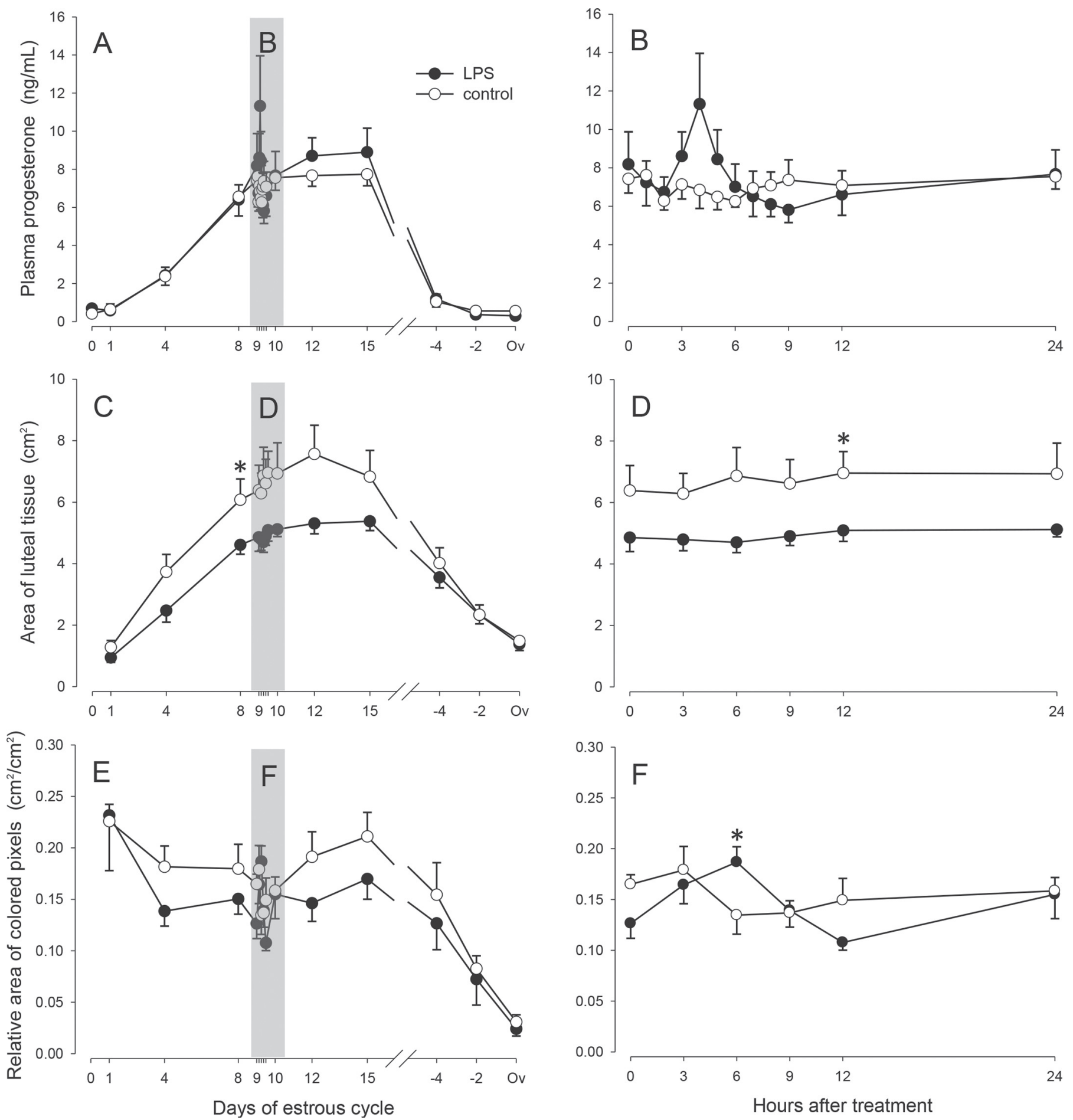

Figure 3. Changes (means \pm SEM) in plasma progesterone concentrations $(A, B)$, the area of luteal tissue (C, D), and the relative area of colored pixels expressing luteal blood flow (E, F) of cows during the whole estrous cycle (A, C, E) and during the first $24 \mathrm{~h}(\mathrm{~B}, \mathrm{D}, \mathrm{F}$, enlargements of shaded areas in A, C, E) after intramammary treatment with either LPS $(\mathrm{n}=8)$ or saline $($ control; $\mathrm{n}=6)$. An asterisk $(*)$ represents the difference between the 2 groups $(P \leq 0.05)$ at times indicated. Day 1 and $\mathrm{Ov}=$ ovulation.

$3 \mathrm{C}$ and $\mathrm{D})$. During the first $24 \mathrm{~h}$ after treatment, the LTA remained constant within the LPS group (Figure $3 \mathrm{D})$.
Relative LBF did not differ between the LPS and the control group before treatment (Figure 3E), but was higher $(P=0.05)$ in LPS-treated cows $6 \mathrm{~h}$ after 
challenge (Figure 3F). Within the LPS group, rLBF increased significantly from 0 to $6 \mathrm{~h}$ and returned thereafter to initial values.

\section{Plasma Concentrations of Prostaglandin $E_{2}$ and Prostaglandin $F_{2 \alpha}$ Metabolites}

Plasma concentrations of $\mathrm{PGE}_{2}$ and PGFM did not differ between LPS and control groups during the first $24 \mathrm{~h}$ after treatment (Figure 4A, B). In this period, $\mathrm{PGE}_{2}$ and PGFM concentrations remained very stable in the LPS group. However, they decreased during the first $6 \mathrm{~h}$ after treatment and increased during the subsequent $6 \mathrm{~h}$ in control cows, returning to initial values at $24 \mathrm{~h}$.

\section{Luteal mRNA Expression}

Changes in mRNA expression of all investigated parameters are shown in Figure 5. No difference regarding the luteal mRNA expression of steroidogenic factors $S T A R$ and HSD3B was noted between the 2 groups $24 \mathrm{~h}$ before and $6 \mathrm{~h}$ after treatment, nor within each group and between the 2 times of analysis (Figure 5A). Expression of apoptotic factor CASP3 was higher $6 \mathrm{~h}$ after treatment compared with $24 \mathrm{~h}$ before treatment within both the LPS $(P=0.004)$ and the control $(P=$ 0.03 ) group, but did not differ between groups at any respective time (Figure 5A).

Expression of TLR2 mRNA was higher $(P=0.005)$ in the LPS group $6 \mathrm{~h}$ after compared with $24 \mathrm{~h}$ before treatment and revealed a higher $(P<0.0001)$ mRNA abundance after treatment in the LPS compared with the control group (Figure 5B). In contrast, expression of TLR 4 neither differed between groups at any time nor changed after treatment within groups (Figure 5B). Lipopolysaccharide treatment increased $(P=0.0005)$ proinflammatory cytokine TNFA, but no difference was observed between groups at any respective time (Figure $5 \mathrm{~B})$.

Luteal mRNA expression of PGES and PGFS differed neither between groups nor within groups and successive time points (Figure 5C). Although there was no difference in the expressions of PTGFR mRNA between $24 \mathrm{~h}$ before and $6 \mathrm{~h}$ after treatment in either LPS or control groups, the mRNA abundance was higher $(P$ $=0.03)$ in the LPS compared with the control group $6 \mathrm{~h}$ after treatment (Figure 5C).

\section{DISCUSSION}

To the best of our knowledge, this is the first detailed description regarding the effects of an experimentally induced mastitis via E. coli LPS on the development
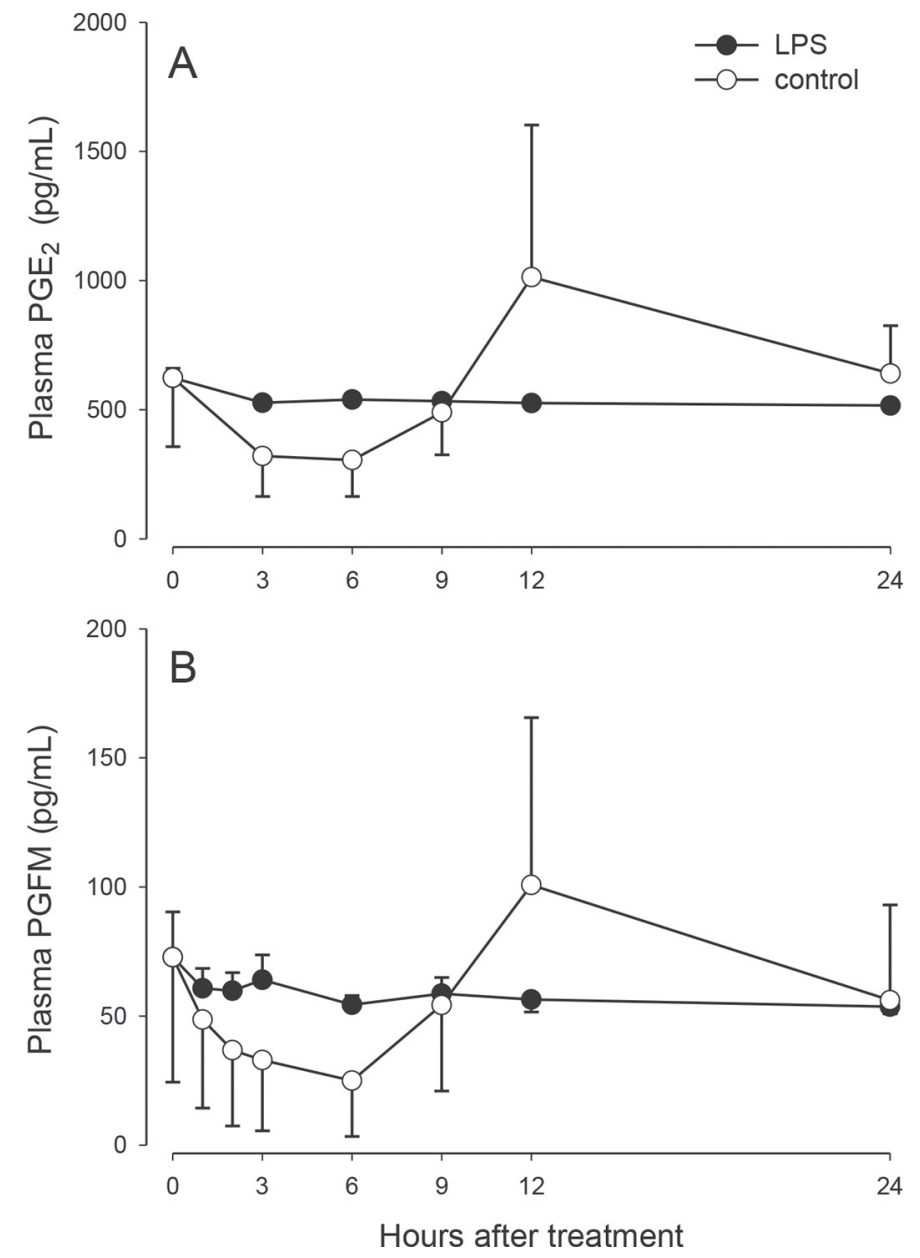

Figure 4. Changes (means \pm SEM) in plasma concentrations of prostaglandin $\mathrm{E}_{2}\left(\mathrm{PGE}_{2} ; \mathrm{A}\right)$ and $\mathrm{PGF}_{2 \alpha}$ metabolites $(\mathrm{PGFM} ; \mathrm{B})$ of cows during the first $24 \mathrm{~h}$ after intramammary treatment with either LPS $(\mathrm{n}=8)$ or saline (control; $\mathrm{n}=6$ ). No significant difference between the 2 groups was noted at the times indicated.

and function of the bovine CL, including analyses of luteal blood flow and gene expression.

In all cows intramammary LPS challenge induced a clinical mastitis with obvious clinical symptoms within $2 \mathrm{~h}$ after treatment. Furthermore, the significant increase in milk SCC at $2 \mathrm{~h} 45 \mathrm{~min}$ indicated the presence of the innate mammary immune response (Wellnitz and Bruckmaier, 2012; Wellnitz et al., 2015). The considerable elevation of SCC was expected because we used a relatively high dosage of LPS (Baumert et al., 2009). The increase in SCC roughly coincided with the increase in rectal temperature, suggesting an association between the local infiltration of PMNL and the release of pyrogenic cytokines.

Plasma $\mathrm{P}_{4}$ concentrations increased significantly between 2 and $4 \mathrm{~h}$ after intramammary LPS challenge, showing consistency with the elevated $\mathrm{P}_{4}$ levels noticed 


\section{A) Steroidogenic factors and apoptosis-related enzyme}
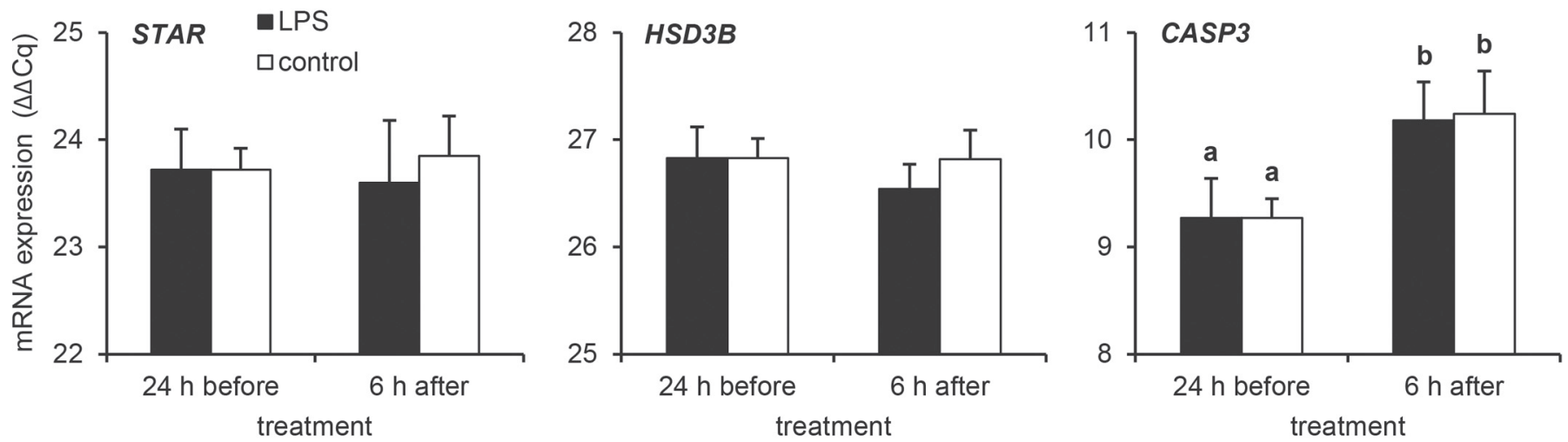

B) Receptors for LPS and proinflammatory cytokine
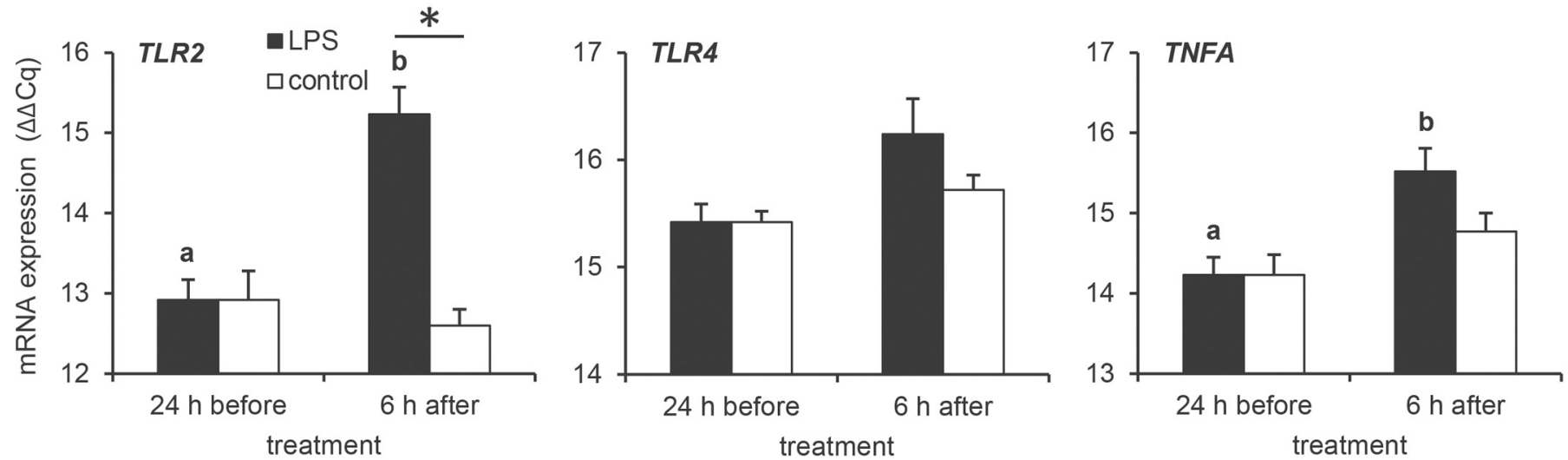

\section{C) Prostaglandin-related factors}
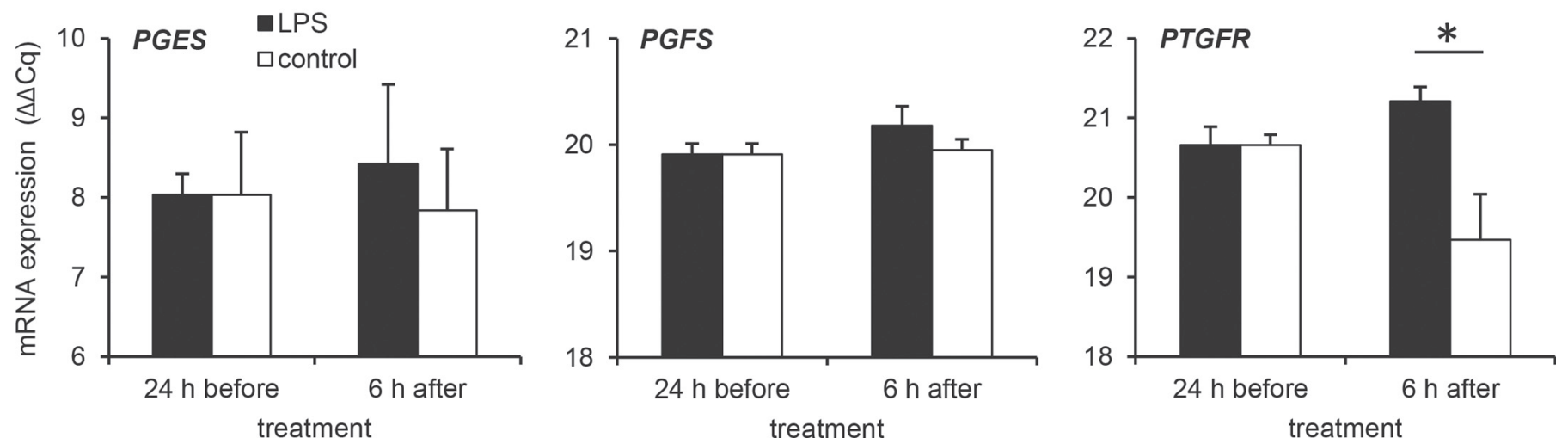

Figure 5. Luteal mRNA expressions (means \pm SEM) of steroidogenic acute regulatory protein $(S T A R)$, 33-hydroxysteroid dehydrogenase (HSD3B), caspase 3 (CASP3), toll-like receptor $(T L R) 2$, TLR4, tumor necrosis factor $\alpha$ (TNFA), prostaglandinE synthase (PGES), PGFS, and prostaglandin F receptor $(P T G F R)$ at $24 \mathrm{~h}$ before and $6 \mathrm{~h}$ after an intramammary treatment of cows with either LPS (black columns; $\mathrm{n}=8)$ or saline (control; white columns; $\mathrm{n}=6$ ). Different letters $(\mathrm{a}, \mathrm{b})$ represent a difference between times $(P \leq 0.05)$ within groups indicated; an asterisk $\left(^{*}\right)$ represents a difference between groups $(P \leq 0.05)$ at times indicated. $\Delta \Delta \mathrm{Cq}=\mathrm{mRNA}$ expression (PCR cycle of quantification) normalized against reference genes and the baseline expression before the treatment. 
within 0.5 (Herzog et al., 2012) and $4 \mathrm{~h}$ (Gilbert et al., 1990) after intravenous LPS treatment. We suggest that the transient increase in $\mathrm{P}_{4}$ was of adrenal origin because a similar $\mathrm{P}_{4}$ pattern was induced by LPS in ovariectomized heifers (Kujjo et al., 1995). Peak $\mathrm{P}_{4}$ and cortisol concentrations were coincident $4 \mathrm{~h}$ after LPS challenge in the present study. The temporary increase in both $\mathrm{P}_{4}$ and cortisol concentrations might be a result of a central activation of the neuroendocrine stress axis induced by the LPS (Suzuki et al., 2001). However, the reduced size of the CL $12 \mathrm{~h}$ after infusion in the LPStreated compared with the control cows was probably not induced by the endotoxin because luteal size was already smaller before treatment. The different sizes of the CL between groups were possibly due to different times of ovulation (within the $36 \mathrm{~h}$ between the second $\mathrm{GnRH}$ treatment and the defined time of ovulation). In contrast, the size-corrected blood flow of the CL did not differ between LPS and control groups before treatment, but increased within $6 \mathrm{~h}$ after LPS challenge. The peak value of rLBF in the LPS group was temporally coincident with the peak values of cardiac frequencies, consistent with organ perfusion depending on cardiac frequency and output (Bose et al., 2015).

In previous studies, the transient increase in plasma $\mathrm{P}_{4}$ concentrations after intravenous (Herzog et al., 2012) or intrauterine (Williams et al., 2008) treatments with LPS was followed by a decrease in plasma $\mathrm{P}_{4}$ due to reduced luteal $\mathrm{P}_{4}$ secretion. Progesterone concentration is correlated with LTA and LBF (Herzog et al., 2010; Lüttgenau et al., 2011b). Thus, consistency exists between the study of Herzog et al. (2012) reporting a depression in $\mathrm{P}_{4}$, LTA, and LBF after intravenous LPS treatment, and our study reporting no depression of any of these parameters. Maintenance of luteal size and function after intramammary LPS treatment compared with the partial luteolysis noticed after intravenous treatment might be due to the LPS being limited to the mammary gland, thus inducing lower concentrations of luteolytic $\mathrm{PGF}_{2 \alpha}$. Our assumption was confirmed by the absence of any increase in plasma PGFM levels after the intramammary LPS challenge in the present study. Consistently, endotoxin caused elevated systemic PGFM concentrations when administered intravenously (Gilbert et al., 1990; Jackson et al., 1990; Herzog et al., 2012), but not when administered into the mammary gland (Jackson et al., 1990). In contrast, cows with natural cases of clinical mastitis (mainly due to gram-negative pathogens) were twice as likely to have altered interestrus intervals (Moore et al., 1991) and had a significantly higher rate of premature luteolysis (Huszenicza et al., 2005) compared with healthy cows. We assume that the prolonged LPS release from gramnegative bacteria in natural cases of mastitis stimulates a sufficient $\mathrm{PGF}_{2 \alpha}$ output of the endometrium to induce luteal regression. In the present study, no difference in plasma $\mathrm{PGE}_{2}$ concentrations after intramammary LPS challenge was noted compared with control cows. As $\mathrm{PGE}_{2}$ is the most potent luteotropic and antiluteolytic factor in the bovine CL (Rekawiecki et al., 2005; Skarzynski et al., 2007), this result is consistent with the fact that no difference was noticed between the 2 groups in luteal morphology and function.

Luteal TNFA mRNA was significantly more abundant following intramammary LPS challenge compared with the control group. The increased concentrations of circulating TNF- $\alpha$ during mastitis may have originated from the mammary gland or could have been produced in response to signals from the mammary gland (Hansen et al., 2004). Production of TNF- $\alpha$ by the bovine CL is of particular interest because TNF- $\alpha$ can exert a direct cytotoxic effect on luteal cells (Petroff et al., 2001).

Intramammary application of LPS induced a tremendous increase in luteal mRNA expression of TLR2 but had no effect on TLR 4 mRNA. At first sight this result seems contradictory because LPS of $E$. coli and other gram-negative bacteria is recognized by TLR 4 (Poltorak et al., 1998), whereas TLR2 binds peptidoglycan and lipoteichoic acid from gram-positive bacteria (Takeda and Akira, 2005). However, previous studies (Hirvonen et al., 1999; Hoeben et al., 2000) provide evidence that LPS is not directly released from the mammary gland into the general circulation. Still, it is the proinflammatory cytokines such as TNF- $\alpha$ that enter the circulation and cause systemic effects. Studies in mice (Matsumura et al., 2000) and humans (Davanian et al., 2012) have clearly demonstrated that TNF- $\alpha$ increase TLR2 mRNA without altering mRNA expression of TLR4. Therefore, we suggest that LPS-induced TNF- $\alpha$ contributes to the observed upregulation of luteal TLR2 mRNA.

In the present study, luteal mRNA expressions of steroidogenic and prostaglandin-related factors were not affected by intramammary application of LPS. This was consistent with the fact that no differences in luteal $\mathrm{P}_{4}$ production and plasma PGFM concentrations were noticed. In contrast, cows with increased PGFM and reduced $\mathrm{P}_{4}$ levels due to intravenous LPS challenge had decreased mRNA expressions of STAR (Herzog et al., 2012) and $H S D 3 B$ (J. Lüttgenau, unpublished data). Likewise, an increased luteal expression of prostaglandin synthases and a reduction in PTGFR mRNA and $S T A R$ and $H S D 3 B$ activities were associated with an exposure to increased amounts of $\mathrm{PGF}_{2 \alpha}$ (Shirasuna et al., 2010; Atli et al., 2012).

Luteal mRNA expression of CASP3 was increased after treatment in both LPS and control groups. As 
$C A S P 3$ is an important mediator of apoptosis, which is activated by $\mathrm{PGF}_{2 \alpha}$ during luteal regression (Stocco et al., 2007), it can be suggested that the physical insult of the CL due to the biopsy can induce luteal $\mathrm{PGF}_{2 \alpha}$ release and apoptosis. However, it was clearly demonstrated that a sequential collection of luteal tissue for biopsy alone does not induce luteal regression (Tsai et al., 2001; Atli et al., 2012). Furthermore, the remaining results from mRNA expression analysis in the present study do not support the assumption of apoptosis due to luteal regression.

Apart from the local inflammation of the mammary gland, intramammary LPS treatment induced severe systemic symptoms, including pyrexia, tachycardia, and tachypnea. Likewise, an acute phase response, characterized by clinical disturbances such as pyrexia and tachycardia, was induced by IMI with E. coli or treatment with LPS (Bannerman et al., 2004; Hertl et al., 2010; Lavon et al., 2011c). In the present study, peak of body temperature was observed $6 \mathrm{~h}$ after LPS challenge. The same elevation of rectal temperature was noticed after IMI with E. coli and was coincident with the maximum concentrations of proinflammatory cytokine TNF- $\alpha$ (Ma et al., 2011). Following intravenous LPS treatment, 3 out of 7 cows had increased body temperature, but all cows showed tachycardia and tachypnea (Herzog et al., 2012). The higher percentage of cows with pyrexia (100 vs. $43 \%$ ) and the higher peak temperatures ( 41.1 to 42.3 vs. 39.5 to $40.4^{\circ} \mathrm{C}$ ) after the intramammary compared with the intravenous application of LPS was unexpected. However, the infections of the mammary gland have been linked particularly with an abundant release of inflammatory mediators and the stimulation of pyrexia (Hertl et al., 2010).

Furthermore, cortisol concentrations were increased after LPS challenge, consistent with previous reports on cows with clinical mastitis (Hockett et al., 2000) and on cows with intramammary (Vernay et al., 2012) and intrauterine (Peter et al., 1989) infusion of E. coli LPS. It is noteworthy that increased cortisol levels in these studies were associated with anovulation. In the present study, 3 out of the 8 cows with intramammary application of LPS during diestrus did not ovulate during the subsequent estrus. Likewise, ovulation was delayed 4 to $14 \mathrm{~d}$ in cows with intravenous LPS treatment during proestrus (Suzuki et al., 2001) and diestrus (Herzog et al., 2012), respectively. In cows with clinical (Barker et al., 1998) and subclinical mastitis (Schrick et al., 2001), anovulation and delayed ovulation were explained by increased cortisol concentrations and suppression of the LH surge. Lavon et al. (2010, 2011b,c) suggested that E. coli LPS in the mammary gland activates the adrenal system that leads to suppression of pulsatile LH secretion and decreased estradiol concentrations, and subsequently to delayed LH surge and ovulation. However, in the present study, cortisol was transiently elevated after LPS challenge on d 9 (i.e., when the potential preovulatory follicle was still small, $<5 \mathrm{~mm}$ ). Therefore, a direct effect of cortisol on follicular capacity to ovulate is questionable. It seems more likely that LPS or LPS-induced secretion of inflammatory mediators impair the development of the preovulatory follicle, as even small follicles are susceptible to endotoxins or cytokines. Previous studies have shown that LPS disturbed the estradiol production of immature granulosa cells isolated from small follicles (Shimizu et al., 2012). Therefore, the LPS-induced damage of small follicle function during folliculogenesis was carried over to the preovulatory follicles (Furman et al., 2014).

In contrast to the short-term increase in cortisol concentrations that peaked $4 \mathrm{~h}$ after LPS treatment, haptoglobin level increased steadily, reaching its peak $3 \mathrm{~d}$ after LPS challenge. Elevated haptoglobin concentrations have been shown to indicate an acute infectious process in dairy cows, and the long-lasting increase was consistent with previous observations in cows with metritis (Huzzey et al., 2009). Therefore, the acute phase response was not only characterized by pyrexia and increased production of inflammatory cytokines, but also by elevated levels of acute phase proteins such as haptoglobin (Uthaisangsook et al., 2002).

In conclusion, LPS-induced mastitis triggers a severe systemic inflammatory response and alters the mRNA abundance of TLR2 and TNFA in the bovine CL. Although intramammary (in contrast to intravenous) LPS challenge was not associated with increased PGFM and did not induce luteolysis, the observed alterations in luteal gene expression may contribute to the reduced fertility in cows with mastitis.

\section{ACKNOWLEDGMENTS}

We acknowledge our colleagues at Veterinary Physiology, Vetsuisse Faculty University of Bern, Switzerland, C. Philipona and Y. Zbinden, for laboratory work, L. Eggerschwiler for organizational support with the cows, and P. Schärli and C. Zbinden for assistance during collection of corpus luteum biopsies. Furthermore, we thank W. Schmid (from Physiology Weihenstephan, Technical University Munich, Germany) for technical assistance. This research did not receive any specific grant from any funding agency in the public, commercial or not-for-profit sector.

\section{REFERENCES}

Alpizar, E., and L. J. Spicer. 1994. Effects of Interleukin-6 on Proliferation and Follicle-Stimulating Hormone-Induced Estradiol Pro- 
duction by Bovine Granulosa-Cells in vitro - Dependence on Size of Follicle. Biol. Reprod. 50:38-43.

Atli, M. O., R. W. Bender, V. Mehta, M. R. Bastos, W. Luo, C. M. Vezina, and M. C. Wiltbank. 2012. Patterns of gene expression in the bovine corpus luteum following repeated intrauterine infusions of low doses of prostaglandin F2alpha. Biol. Reprod. 86:130.

Bannerman, D. D., M. J. Paape, J. W. Lee, X. Zhao, J. C. Hope, and P. Rainard. 2004. Escherichia coli and Staphylococcus aureus elicit differential innate immune responses following intramammary infection. Clin. Diagn. Lab. Immunol. 11:463-472.

Barker, A. R., F. N. Schrick, M. J. Lewis, H. H. Dowlen, and S. P. Oliver. 1998. Influence of clinical mastitis during early lactation on reproductive performance of Jersey cows. J. Dairy Sci. 81:1285-1290.

Barros, C. M., J. G. Betts, W. W. Thatcher, and P. J. Hansen. 1992. Possible mechanisms for reduction of circulating concentrations of progesterone by interferon-alpha in cows: Effects on hyperthermia, luteal cells, metabolism of progesterone and secretion of LH. J. Endocrinol. 133:175-182.

Baumert, A., R. M. Bruckmaier, and O. Wellnitz. 2009. Dose dependant SCC changes after intramammary lipopolysaccharide challenge. Milchwissenschaft 64:119-121.

Bose, E. L., M. Hravnak, and M. R. Pinsky. 2015. The interface between monitoring and physiology at the bedside. Crit. Care Clin. $31: 1-24$.

Bruckmaier, R. M., M. Schällibaum, and J. W. Blum. 1993. Escherichia coli endotoxin-induced mastitis in dairy cows: Changes and importance of insulin-like growth factor I and oxytocin. Milchwissenschaft 48:374-378.

Davanian, H., T. Bage, J. Lindberg, J. Lundeberg, H. Q. Concha, M. Sallberg Chen, and T. Yucel-Lindberg. 2012. Signaling pathways involved in the regulation of TNFalpha-induced toll-like receptor 2 expression in human gingival fibroblasts. Cytokine 57:406-416.

Furman, O., G. Leitner, Z. Roth, Y. Lavon, S. Jacoby, and D. Wolfenson. 2014. Experimental model of toxin-induced subclinical mastitis and its effect on diruption of follicular function in cows. Theriogenology 82:1165-1172.

Gilbert, R. O., W. T. Bosu, and A. T. Peter. 1990. The effect of Escherichia coli endotoxin on luteal function in Holstein heifers. Theriogenology 33:645-651.

Hansen, P. J., P. Soto, and R. P. Natzke. 2004. Mastitis and fertility in cattle - Possible involvement of inflammation or immune activation in embryonic mortality. Am. J. Reprod. Immunol. 51:294-301.

Hertl, J. A., Y. T. Grohn, J. D. Leach, D. Bar, G. J. Bennett, R N. Gonzalez, B. J. Rauch, F. L. Welcome, L. W. Tauer, and Y. H. Schukken. 2010. Effects of clinical mastitis caused by grampositive and gram-negative bacteria and other organisms on the probability of conception in New York State Holstein dairy cows. J. Dairy Sci. 93:1551-1560.

Herzog, K., M. Brockhan-Lüdemann, M. Kaske, N. Beindorff, V. Paul, H. Niemann, and H. Bollwein. 2010. Luteal blood flow is a more appropriate indicator for luteal function during the bovine estrous cycle than luteal size. Theriogenology 73:691-697.

Herzog, K., K. Strüve, J. P. Kastelic, M. Piechotta, S. E. Ulbrich, C. Pfarrer, K. Shirasuna, T. Shimizu, A. Miyamoto, and H. Bollwein. 2012. Escherichia coli lipopolysaccharide administration transiently suppresses luteal structure and function in diestrous cows. Reproduction 144:467-476.

Hirvonen, J., K. Eklund, A. M. Teppo, G. Huszenicza, M. Kulcsar, H. Saloniemi, and S. Pyorala. 1999. Acute phase response in dairy cows with experimentally induced Escherichia coli mastitis. Acta Vet. Scand. 40:35-46.

Hockett, M. E., F. M. Hopkins, M. J. Lewis, A. M. Saxton, H. H. Dowlen, S. P. Oliver, and F. N. Schrick. 2000. Endocrine profiles of dairy cows following experimentally induced clinical mastitis during early lactation. Anim. Reprod. Sci. 58:241-251.

Hoeben, D., C. Burvenich, E. Trevisi, G. Bertoni, J. Hamann, R. M. Bruckmaier, and J. W. Blum. 2000. Role of endotoxin and TNFalpha in the pathogenesis of experimentally induced coliform mastitis in periparturient cows. J. Dairy Res. 67:503-514.

Huszenicza, G., S. Jánosi, M. Kulcsár, P. Kóródi, J. Reiczigel, L. Kátai, A. R. Peters, and F. De Rensis. 2005. Effects of clinical mastitis on ovarian function in post-partum dairy cows. Reprod. Domest. Anim. 40:199-204.

Huzzey, J. M., T. F. Duffield, S. J. LeBlanc, D. M. Veira, D. M. Weary, and M. A. von Keyserlingk. 2009. Short communication: Haptoglobin as an early indicator of metritis. J. Dairy Sci. 92:621-625.

Jackson, J. A., D. E. Shuster, W. J. Silvia, and R. J. Harmon. 1990 Physiological responses to intramammary or intravenous treatment with endotoxin in lactating dairy cows. J. Dairy Sci. 73:627-632.

Kujjo, L. L., W. T. Bosu, and G. I. Perez. 1995. Opioid peptides involvement in endotoxin-induced suppression of LH secretion in ovariectomized Holstein heifers. Reprod. Toxicol. 9:169-174.

Lavon, Y., E. Ezra, G. Leitner, and D. Wolfenson. 2011a. Association of conception rate with pattern and level of somatic cell count elevation relative to time of insemination in dairy cows. J. Dairy Sci. 94:4538-4545.

Lavon, Y., G. Leitner, T. Goshen, R. Braw-Tal, S. Jacoby, and D. Wolfenson. 2008. Exposure to endotoxin during estrus alters the timing of ovulation and hormonal concentrations in cows. Theriogenology 70:956-967.

Lavon, Y. G. Leitner, E. Klipper, U. Moallem, R. Meidan, and D. Wolfenson. 2011b. Subclinical, chronic intramammary infection lowers steroid concentrations and gene expression in bovine preovulatory follicles. Domest. Anim. Endocrinol. 40:98-109.

Lavon, Y., G. Leitner, U. Moallem, E. Klipper, H. Voet, S. Jacoby, G. Glick, R. Meidan, and D. Wolfenson. 2011c. Immediate and carryover effects of gram-negative and gram-positive toxin-induced mastitis on follicular function in dairy cows. Theriogenology 76:942-953.

Lavon, Y., G. Leitner, H. Voet, and D. Wolfenson. 2010. Naturally occurring mastitis effects on timing of ovulation, steroid and gonadotrophic hormone concentrations, and follicular and luteal growth in cows. J. Dairy Sci. 93:911-921.

Livak, K. J., and T. D. Schmittgen. 2001. Analysis of relative gene expression data using real-time quantitative PCR and the 2(-Delta Delta $\mathrm{C}(\mathrm{T})$ ). Methods 25:402-408

Lüttgenau, J., N. Beindorff, S. E. Ulbrich, J. P. Kastelic, and H. Bollwein. 2011a. Low plasma progesterone concentrations are accompanied by reduced luteal blood flow and increased size of the dominant follicle in dairy cows. Theriogenology 76:12-22.

Lüttgenau, J., S. E. Ulbrich, N. Beindorff, A. Honnens, K. Herzog, and H. Bollwein. 2011b. Plasma progesterone concentrations in the mid-luteal phase are dependent on luteal size, but independent of luteal blood flow and gene expression in lactating dairy cows. Anim. Reprod. Sci. 125:20-29.

Ma, J. L., Y. H. Zhu, L. Zhang, Z. Y. Zhuge, P. Q. Liu, X. D. Yan, H S. Gao, and J. F. Wang. 2011. Serum concentration and mRNA expression in milk somatic cells of toll-like receptor 2, toll-like receptor 4 , and cytokines in dairy cows following intramammary inoculation with Escherichia coli. J. Dairy Sci. 94:5903-5912.

Matsumura, T., A. Ito, T. Takii, H. Hayashi, and K. Onozaki. 2000. Endotoxin and cytokine regulation of toll-like receptor (TLR) 2 and TLR4 gene expression in murine liver and hepatocytes. J. Interferon Cytokine Res. 20:915-921.

Mishra, D. P., H. H. Meyer, and B. S. Prakash. 2003. Validation of a sensitive enzymeimmunoassay for 13,14-dihydro-15-keto-PGF2alpha in buffalo plasma and its application for reproductive health status monitoring. Anim. Reprod. Sci. 78:33-46.

Moore, D. A., J. S. Cullor, R. H. Bondurant, and W. M. Sischo. 1991. Preliminary field evidence for the association of clinical mastitis with altered interestrus intervals in dairy cattle. Theriogenology $36: 257-265$.

Peter, A. T., W. T. Bosu, and R. J. DeDecker. 1989. Suppression of preovulatory luteinizing hormone surges in heifers after intrauterine infusions of Escherichia coli endotoxin. Am. J. Vet. Res. 50:368-373.

Petroff, M. G., B. K. Petroff, and J. L. Pate. 2001. Mechanisms of cytokine-induced death of cultured bovine luteal cells. Reproduction 121:753-760.

Pinedo, P. J., P. Melendez, J. A. Villagomez-Cortes, and C. A. Risco. 2009. Effect of high somatic cell counts on reproductive performance of Chilean dairy cattle. J. Dairy Sci. 92:1575-1580. 
Pistek, V. L., R. W. Furst, H. Kliem, S. Bauersachs, H. H. Meyer, and S. E. Ulbrich. 2013. HOXA10 mRNA expression and promoter DNA methylation in female pig offspring after in utero estradiol17beta exposure. J. Steroid Biochem. Mol. Biol. 138:435-444.

Poltorak, A., X. He, I. Smirnova, M. Y. Liu, C. Van Huffel, X. Du, D. Birdwell, E. Alejos, M. Silva, C. Galanos, M. Freudenberg, P. Ricciardi-Castagnoli, B. Layton, and B. Beutler. 1998. Defective LPS signaling in C3H/HeJ and C57BL/10ScCr mice: Mutations in Tlr4 gene. Science 282:2085-2088.

Rekawiecki, R., M. Nowik, and J. Kotwica. 2005. Stimulatory effect of LH, PGE2 and progesterone on StAR protein, cytochrome P450 cholesterol side chain cleavage and 3beta hydroxysteroid dehydrogenase gene expression in bovine luteal cells. Prostaglandins Other Lipid Mediat. 78:169-184.

Roth, Z., A. Dvir, D. Kalo, Y. Lavon, O. Krifucks, D. Wolfenson, and G. Leitner. 2013. Naturally occurring mastitis disrupts developmental competence of bovine oocytes. J. Dairy Sci. 96:6499-6505.

Schrick, F. N., M. E. Hockett, A. M. Saxton, M. J. Lewis, H. H. Dowlen, and S. P. Oliver. 2001. Influence of subclinical mastitis during early lactation on reproductive parameters. J. Dairy Sci. 84:1407-1412.

Schukken, Y., M. Chuff, P. Moroni, A. Gurjar, C. Santisteban, F. Welcome, and R. Zadoks. 2012. The "other" gram-negative bacteria in mastitis: Klebsiella, serratia, and more. Vet. Clin. North Am. Food Anim. Pract. 28:239-256.

Shimizu, T., K. Miyauchi, K. Shirasuna, H. Bollwein, F. Magata, C. Murayama, and A. Miyamoto. 2012. Effects of lipopolysaccharide (LPS) and peptidoglycan (PGN) on estradiol production in bovine granulosa cells from small and large follicles. Toxicol. In Vitro 26:1134-1142.

Shirasuna, K., K. Sasahara, M. Matsui, T. Shimizu, and A. Miyamoto. 2010. Prostaglandin F2alpha differentially affects mRNA expression relating to angiogenesis, vasoactivation and prostaglandins in the early and mid corpus luteum in the cow. J. Reprod. Dev. 56:428-436.

Skarzynski, D. J., Y. Miyamoto, and K. Okuda. 2000. Production of prostaglandin $\mathrm{f}(2 \mathrm{alpha})$ by cultured bovine endometrial cells in response to tumor necrosis factor alpha: Cell type specificity and intracellular mechanisms. Biol. Reprod. 62:1116-1120.

Skarzynski, D. J., I. Woclawek-Potocka, A. Korzekwa, M. M. Bah, K. Piotrowska, B. Barszczewska, and K. Okuda. 2007. Infusion of exogenous tumor necrosis factor dose dependently alters the length of the luteal phase in cattle: differential responses to treatment with indomethacin and L-NAME, a nitric oxide synthase inhibitor. Biol. Reprod. 76:619-627.

Stocco, C., C. Telleria, and G. Gibori. 2007. The molecular control of corpus luteum formation, function, and regression. Endocr. Rev. 28:117-149.
Suzuki, C., K. Yoshioka, S. Iwamura, and H. Hirose. 2001. Endotoxin induces delayed ovulation following endocrine aberration during the proestrous phase in Holstein heifers. Domest. Anim. Endocrinol. 20:267-278.

Takeda, K., and S. Akira. 2005. Toll-like receptors in innate immunity, Int. Immunol. 17:1-14.

Thun, R., E. Eggenberger, K. Zerobin, T. Luscher, and W. Vetter. 1981. Twenty-four-hour secretory pattern of cortisol in the bull: evidence of episodic secretion and circadian rhythm. Endocrinology 109:2208-2212.

Tichopad, A., R. Kitchen, I. Riedmaier, C. Becker, A. Stahlberg, and M. Kubista. 2009. Design and optimization of reverse-transcription quantitative PCR experiments. Clin. Chem. 55:1816-1823.

Tsai, S. J., K. Kot, O. J. Ginther, and M. C. Wiltbank. 2001. Temporal gene expression in bovine corpora lutea after treatment with PGF2alpha based on serial biopsies in vivo. Reproduction 121:905-913.

Uthaisangsook, S., N. K. Day, S. L. Bahna, R. A. Good, and S. Haraguchi. 2002. Innate immunity and its role against infections. Ann. Allergy Asthma Immunol. 88:253-264.

Vernay, M. C., O. Wellnitz, L. Kreipe, H. A. van Dorland, and R. M. Bruckmaier. 2012. Local and systemic response to intramammary lipopolysaccharide challenge during long-term manipulated plasma glucose and insulin concentrations in dairy cows. J. Dairy Sci. 95:2540-2549.

Walsh, S. W., E. J. Williams, and A. C. Evans. 2011. A review of the causes of poor fertility in high milk producing dairy cows. Anim. Reprod. Sci. 123:127-138.

Wellnitz, O., E. T. Arnold, and R. M. Bruckmaier. 2011. Lipopolysaccharide and lipoteichoic acid induce different immune responses in the bovine mammary gland. J. Dairy Sci. 94:5405-5412.

Wellnitz, O., and R. M. Bruckmaier. 2012. The innate immune response of the bovine mammary gland to bacterial infection. Vet. J. 192:148-152.

Wellnitz, O., C. Zbinden, J. Lüttgenau, H. Bollwein, and R. M. Bruckmaier. 2015. Different chronological patterns of appearance of blood derived milk components during mastitis indicate different mechanisms of transfer from blood into milk. J. Dairy Res. $82: 322-327$

Williams, E. J., K. Sibley, A. N. Miller, E. A. Lane, J. Fishwick, D. M. Nash, S. Herath, G. C. England, H. Dobson, and I. M. Sheldon. 2008. The effect of Escherichia coli lipopolysaccharide and tumour necrosis factor alpha on ovarian function. Am. J. Reprod. Immunol. 60:462-473.

Wilson, D. J., R. N. Gonzalez, and H. H. Das. 1997. Bovine mastitis pathogens in New York and Pennsylvania: Prevalence and effects on somatic cell count and milk production. J. Dairy Sci. 80:2592-2598. 